\title{
EFFECTS OF FIRE ON ECTOMYCORRHIZAL FUNGI, SPORE DISPERSAL AND DEPENDENT FLORA ESTABLISHMENT IN SOILS
}

\author{
STEVEN L. MILLER $\downarrow$ DEPARTMENT OF BOTANY \\ NANCY L. STANTON $\bullet$ DEPARTMENT OF ZOOLOGY AND PHYSIOLOGY \\ STEPHEN E. WILLIAMS $\downarrow$ PLANT, SOIL AND INSECT SCIENCES \\ UNIVERSITY OF WYOMING $\bullet$ LARAMIE
}

\begin{abstract}
Movement of ectomycorrhizal fungal propagules by small mammals into burned areas of the Huck fire, John D. Rockefeller Memorial Parkway, was monitored for a third field season by live-trapping small mammals in burned and unburned forest sites and examining spores contained in their fecal pellets. As in the first two years, three species of small mammals were commonly trapped including the white-footed deermouse (Peromyscus maniculatus), least chipmunk (Tamias minimus) and southern red-backed vole (Clethrionomys gapperi).
\end{abstract}

Analyses of the fecal samples and small mammal populations from the third year remain to be completed, however, results from the previous two field seasons show that the three species of small mammals exhibited different degrees of mycophagy. The white-footed deermouse fed on a variety of fungi when sporocarps were available. The 1989 field season was dry and few fungal sporocarps formed. Spores of 13 different species of fungi were contained in the fecal pellets from the white-footed deermouse in 1989 (Table 1). The-maximum frequency of individual deermice with spores of a particular fungal genus occurred with Morchella sp. and was approximately $16.7 \%$. Rainfall was higher in both the 1990 and 1991 field seasons and sporocarp production was also high. Fecal pellets of the white-footed deermouse from 1990 contained spores from 20 fungal species, but the maximum frequency of individual deermice with spores was $18.3 \%$ for a Cortinarius sp., only slightly higher than the maximum in the 1989 field season (Table 2).

The least chipmunk, considered to be more of a generalist, fed on both vegetation and fungi in all fecal samples examined to date. Combining all treatments, chipmunks consumed only seven species of fungi in 1989 (Table 1). The genus Rhizopogon was found in $85.7 \%$ of the 21 chipmunks trapped, the maximum frequency value for 1989 . The 1990 fecal samples from the least chipmunk contained spores from ten fungal species, but the maximum frequency of chipmunks with spores of a particular fungus dropped to $16.7 \%$ for a Cortinarius sp. (Table 2).

The red-backed vole consumed the greatest diversity and quantity of fungi. In 1989, 18 species of fungi were recovered from vole fecal pellets, with a maximum frequency value of $58.6 \%$ of the voles with Rhizopogon spores (Table 1). Twenty-three species of fungi were consumed in 1990 by the red-backed voles examined and $37.5 \%$ of all voles consumed spores of Cortinarius sp. (Table 2).

During the first year of trapping, no voles were captured in the burned area, suggesting that voles were not acting as strong vectors for dispersal of 
Table 1. Frequencies (percent of occurrence) of fungi for burn and unburned control treatments combined by small mammal species, 1989. Number in parentheses following each small mammal denotes sum of captures throughout the entire trapping season.

\begin{tabular}{|c|c|c|c|c|}
\hline $\begin{array}{c}\text { Fungal } \\
\text { Genus (or Family) }\end{array}$ & $\begin{array}{l}\text { Fungal } \\
\text { Habit }\end{array}$ & $\begin{array}{l}\text { White-footed } \\
\text { deermouse (84) }\end{array}$ & $\begin{array}{l}\text { Red-backed } \\
\text { vole (29) }\end{array}$ & $\begin{array}{c}\text { Least } \\
\text { chipmunk (21) }\end{array}$ \\
\hline Cortinarius & ectomycorrhizal & 9.5 & 37.9 & 9.5 \\
\hline Gautieria & ectomycorrhizal & 1.2 & 3.5 & 9.5 \\
\hline Geopora & ectomycorrhizal & 0.0 & 6.9 & 0.0 \\
\hline Gloeophyllum & saprophytic & 2.4 & 6.9 & 0.0 \\
\hline Glomaceae & endomycorrhizal & 1.2 & 0.0 & 0.0 \\
\hline Gomphidiaceae & ectomycorrhizal & 0.0 & 13.8 & 0.0 \\
\hline Hymenogaster & ectomycorrhizal & 0.0 & 0.0 & 4.8 \\
\hline Hysterangium & ectomycorrhizal & 2.4 & 24.1 & 4.8 \\
\hline Leucogaster & ectomycorrhizal & 0.0 & 0.0 & 4.8 \\
\hline Leucophleps & ectomycorrhizal & 0.0 & 17.2 & 0.0 \\
\hline Melanogaster & ectomycorrhizal & 1.2 & 0.0 & 0.0 \\
\hline Morchella & facultative & 16.7 & 34.5 & 4.8 \\
\hline Naematoloma & saprophytic & 1.2 & 10.3 & 0.0 \\
\hline Pachylepyrium & saprophytic & 1.2 & 0.0 & 0.0 \\
\hline Pholiota & saprophytic & 4.8 & 13.8 & 0.0 \\
\hline Psathyrella & saprophytic & 0.0 & 6.9 & 0.0 \\
\hline Rhizopogon & ectomycorrhizal & 8.3 & 58.6 & 85.7 \\
\hline Russulaceae & ectomycorrhizal & 7.1 & 48.3 & 0.0 \\
\hline \multicolumn{5}{|c|}{ Unknown Basidiomycetes } \\
\hline Unknown 3 & ? & 0.0 & 3.5 & 0.0 \\
\hline Unknown 6 & $?$ & 0.0 & 10.3 & 0.0 \\
\hline \multicolumn{5}{|c|}{ Unknown Ascomycetes } \\
\hline Unknown 1 & $?$ & 9.5 & 3.5 & 0.0 \\
\hline Unknown 2 & $?$ & 1.2 & 0.0 & 0.0 \\
\hline Unknown 4 & $?$ & 0.0 & 3.5 & 0.0 \\
\hline Unknown 5 & ? & 0.0 & 3.5 & 0.0 \\
\hline
\end{tabular}

spores into burns. Fecal samples from white-footed deermouse trapped in both east- and west-facing burns in 1989 , however, contained spores of three ectomycorrhizal fungi that produced sporocarps only in the unburned control forest. This indicates that at least some deermice were foraying into the control areas to eat fungi, and then returning to the burn. Similarly, at least some least chipmunks captured in the west-facing burn during 1989 had eaten two species of ectomycorrhizal fungi that had fruited in unburned areas.

During the second year of trapping, there were three documented dispersal events of small mammals moving from unburned forest to the burn, one for each of the three major small mammals trapped regularly at the sites. In addition, there were seven "assumed" events of dispersal by red-backed voles which were captured within the burn treatment but never recaptured in the unburned plots. Analysis of fecal pellets from the individuals trapped in both the burned and unburned forest, and individuals trapped in areas not normally occupied by that particular small mammal species, contained both hypogeous and epigeous ectomycorrhizal fungal species as well as saprophytes and facultative ectendomycorrhizal species (Table 3). 
Table 2. Frequencies (percent of occurrence) of fungi for burn and unburned control treatments combined by small mammal species, 1990. Number in parentheses following each small mammal denotes sum of captures throughout the entire trapping season.

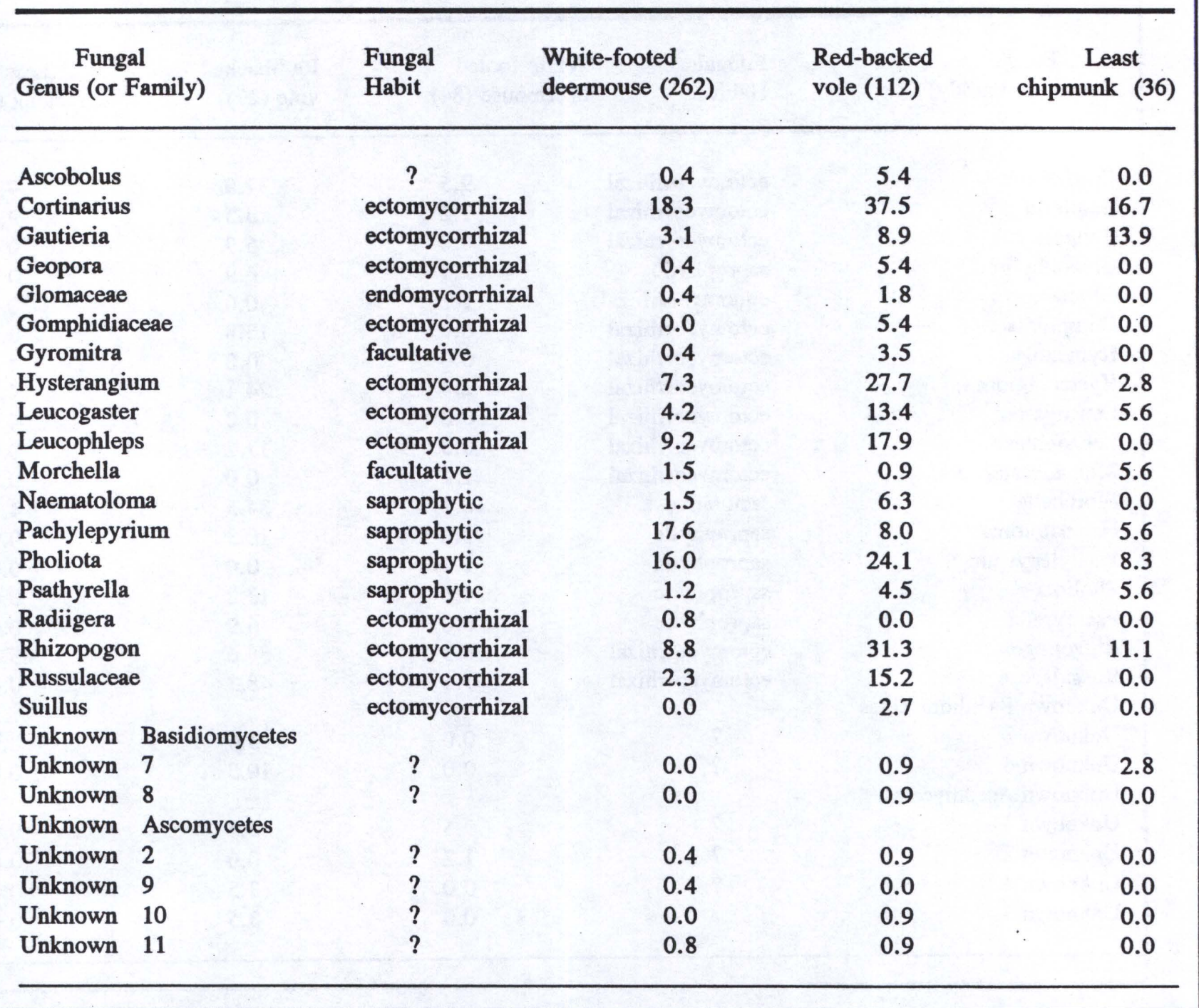

Two species of conifer seedlings were recruited into the burned areas during the first three field seasons post-fire in the Huck burn. Lodgepole pine (Pinus contorta) recruitment was highest during the first field season, but germination occurred at much lower rates in years 2 and 3 (Fig. 1). Subalpine fir (Abies lasiocarpa) was present, especially in June of year 1 but was rarely encountered thereafter. Survivorship of lodgepole pine seedlings flagged at the end of the first field season was still nearly $100 \%$ by spring of the second field season and remained high even into year 3. Mortality that did occur was. due primarily to large mammal disturbance.
This is the final year of the proposed study. Work yet to be performed includes completion of the remaining fecal analyses, counts of Cenococcum sclerotia, and analysis of the small mammal data taken in 1991. In addition, it would be desirable to map the data in such a way that both the small mammal distribution and corresponding spore load could be observed. At this time there appear to be no problems that may impede completion of the proposed research within the time remaining. 
Table 3. Fungal genera present in fecal pellets from small mammals trapped both in burned and unburned plots or suspected of moving between treatments at the Huck fire sites, John D. Rockefeller Memorial Parkway, 1990.

SMALL MAMMALS

FUNGI

\begin{tabular}{|c|c|c|}
\hline & Hypogeous & Epigeous \\
\hline Clethrionomys gapperi & $\begin{array}{l}\text { Rhizopogon--e }{ }^{1} \\
\text { Hysterangium--e } \\
\text { Gautieria--e } \\
\text { Leucogaster--e } \\
\text { Glomus--en }\end{array}$ & $\begin{array}{l}\text { Psathyrella--s } \\
\text { Morchella--f } \\
\text { Russula/Lactarius--e } \\
\text { Pholiota--s }{ }^{4} \\
\text { Naematoloma--s } \\
\text { Gyromitra--u }{ }^{3} \\
\text { Cortinarius--e } \\
\text { Pachylepyrium--s }\end{array}$ \\
\hline Tamias minimus & $\begin{array}{l}\text { Hysterangium } \\
\text { Gautieria } \\
\text { Leucogaster } \\
\text { Rhizopogon }\end{array}$ & $\begin{array}{l}\text { Pholiota } \\
\text { Psathyrella } \\
\text { Morchella } \\
\text { Peziza } \\
\text { Cortinarius } \\
\text { Pachylepyrium }\end{array}$ \\
\hline Peromyscus maniculatus & $\begin{array}{l}\text { Rhizopogon } \\
\text { Gautieria } \\
\text { Leucogphleps--e } \\
\text { Hysterangium } \\
\text { Radiigera--e } \\
\text { Geopora--e } \\
\text { Leucogaster }\end{array}$ & $\begin{array}{l}\text { Morchella } \\
\text { Pachylepyrium } \\
\text { Cortinarius } \\
\text { Pholiota } \\
\text { Russula/Lactarius }\end{array}$ \\
\hline
\end{tabular}

'ectomycorrhizal habitat; ${ }^{2}$ facultative habit; ${ }^{3}$ habit unknown; ${ }^{4}$ saprophytic habit; .

svesicular-arbuscular endomycorrhizal habit

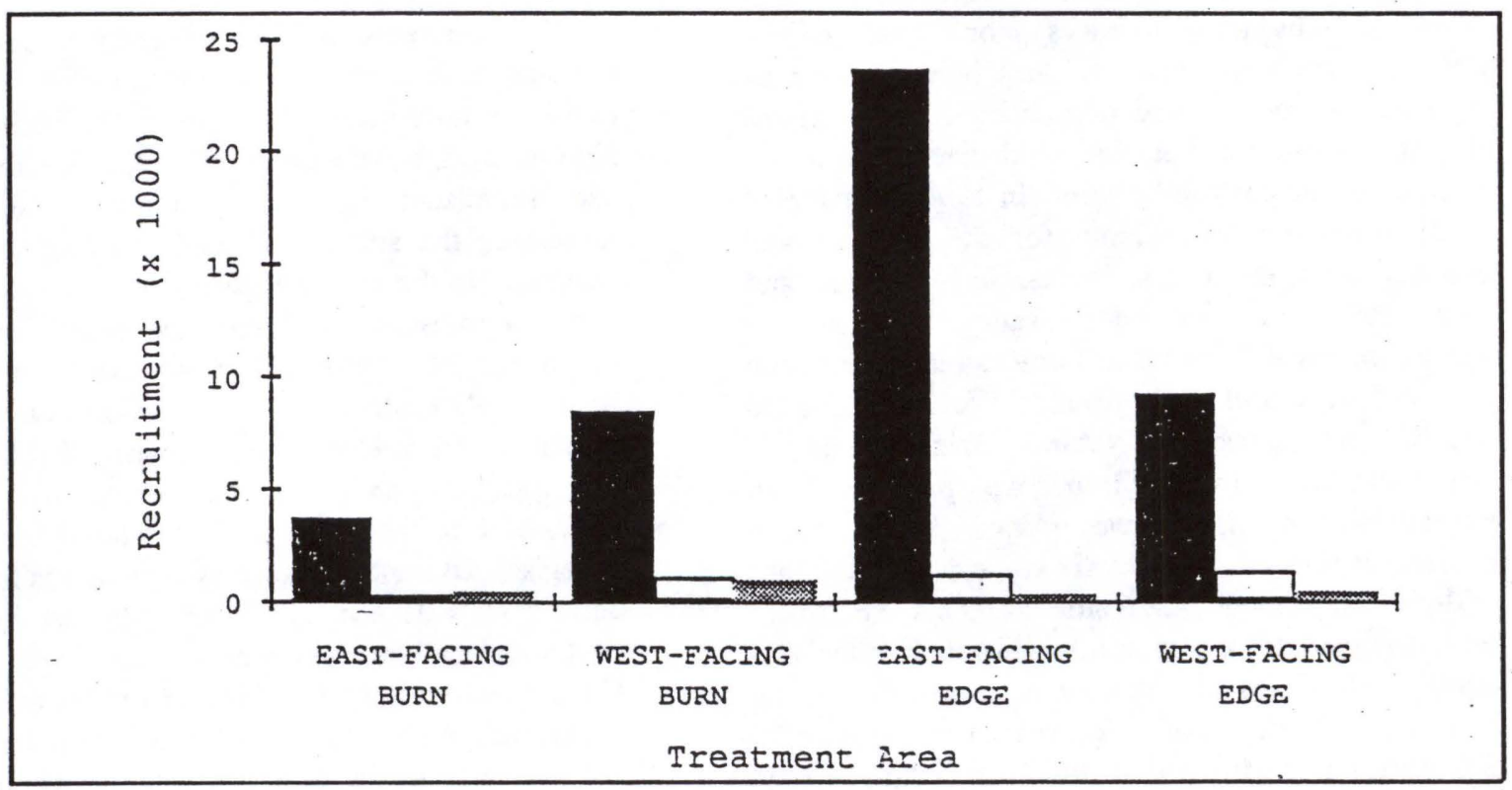

Figure 1. Recruitment of lodgepole pine (Pinus contorta) seedlings at the Huck fire sites in 1000's of seedlings per hectare. $\square$ denotes seedlings recruited in 1989, $\square$ denotes seedlings recruited in 1990, and 